\title{
Financial Performance Analysis of Islamic Banks in Bangladesh: A Case Study on Islami Bank Bangladesh Limited (IBBL)
}

\author{
Jaba Chakraborty ${ }^{1, *}$, Farjana Salam ${ }^{1}$, Md. Ghulam Rabbany ${ }^{2}$ \\ ${ }^{1}$ Department of Business Administration,Bangladesh University, Dhaka, Bangladesh \\ ${ }^{2}$ Department of Agribusiness \& Marketing, Sher-e-Bangla Agricultural University, Dhaka, Bangladesh
}

Email address:

j.chakrobarty@yahoo.com (J. Chakrobarty), shazadi_farj@yahoo.com (F.Salam), tonoy_mkt@yahoo.com (Md. G.Rabbany)

\section{To cite this article:}

Jaba Chakraborty, Farjana Salam, Md. Ghulam Rabbany. Financial Performance Analysis of Islamic Banks in Bangladesh: A Case Study on Islami Bank Bangladesh Limited (IBBL). International Journal of Economics, Finance and Management Sciences.

Vol. 3, No. 2, 2015, pp. 99-106. doi: 10.11648/j.ijefm.20150302.14

\begin{abstract}
Banking means deposit mobilization and deployment of those deposits into advances or investments in different sectors. The element of interest has been for long used as main instruments for deposit mobilization and the deployment of funds therefore.In the Muslim world, it remains a deep cry in peoples' hearts to fashion and design their economic lives in accordance with the percepts of Islam. It is committed to conduct all banking and investment activities on the basis of interestfree unveiled a new horizon and ushered in a new silver lining of hope towards materializing a long cherished dream of the people of Bangladesh for doing their Banking transitions in line with what is prescribed by Islam. That is why, considering the performance of IBBL, on attempt has been made in this paper to study the financial analysis procedure of IBBL. We have rendered our knowledge to present this study on all Performance of Islami Bank Bangladesh Limited. In this study, it is shown that various operational activities can be used in the evaluation of operation of this Bank. Considering the productivity ratio, current ratio quick ratio, profitability ratio,solvency ratio we can find that this bank is increasing its performance efficiency.
\end{abstract}

Keywords: Islamic Banking, Riba, Interest Free Banking, Financial Performance, Productivity

\section{Introduction}

Islami Bank Bangladesh Limited (IBBL) is trying to establish the maximum welfare of the society by maintaining the principles of Islamic Shari'ah which is based on "Quran" and "Sunnah". Since 13 March 1983, IBBL is the pioneer in welfare banking in this subcontinent and it is trying to do all its activities for the betterment of its depositors. The Islamic Shariah prohibits the payment or acceptance of interest fees for the lending and accepting of money. In this regard to establish a banking world that run according to Shariah, the concept of Islamic Banking Arise. The definition of Islamic Bank, as approved by the General Secretariat of the OIC, is stated in the following manner. "An Islamic Bank is a Financial Institution whose statutes, rules and procedures expressly state its commitment to the principles of Islamic Shariah and to the banning of the receipt and payment of interest on any of its operation. "This study is an attempt to gain the knowledge of evaluating the performance of Islami Bank Bangladesh Ltd. in terms of productivity and effectiveness. Also, analyze and discuss the five years performance from fiscal year 2006-2010 to evaluate the position of Islami Bank Bangladesh Ltd.

\section{Statement of the Problem}

Islami bank Bangladesh ltd. is one of the renowned organization which is conducted by Islamic shariah. The activates of Islami Ban are different from the activities of other conventional Bank. Islami Bank follows the Islamic rules and regulation for conducting their several activities. So it is necessary to know the overall activities and performance of Islami Bank Bangladesh Limited.

\section{Rationale of the Study}

There are two types of banking system in Bangladesh. One is conventional which is interest based another is Islamic, which is interest free. Islamic banks operate their transactions in accordance with the principles of Islamic Shariah. A lot of 
research has been conducted on this bank. In feet, Islamic ideology may persist only in an Islamic country but in a country where conventional systems of banking prevail, it may a lot of problems. So, the problems and prospects of Islamic bank Bangladesh system vis-à-vis. Such study is considered necessary and this study aims to fulfill this demand of the time. A study convening all these issues becomes and expected to be very significant both from the practical view points to the best of knowledge of the researcher.

\section{The Objectives of the Study}

The main objectives of the study are as follows:

1. To measure the growth rate of IBBL.

2. To measure the profitability ratio of IBBL.

3 . To measure the productivity of IBBL.

4. To know the financial performance of IBBL.

\section{Review of Related Literature}

A brief summary of the researcher relevant to Performance analysis of IBBL is enumerated below will support this assumption:

Ahmed, Jamil (1990) has showed in his PhD thesis entitled the contribution of Islamic Banking to economic Development. A case of the Sudan that the Islamic banks investment and in short term and finance and have done little to promote long-term finance.

Alam, Misir (1998) made an important study on "Analysis of comparative financial performance in banking sector of Bangladesh. A study of interest free and traditional banks" the study on Arab Bangladesh banks Ltd. and Islami bank Bangladesh Ltd. was made in terms of profitability productivity, liquidity and contribution to National Exchequer.

Hamid, Abdul (1999) presented a paper at the international conference on Islamic Economics in the $21^{\text {st }}$ century (held) in Malaysia from 09 to 12 August 1999) entitled Islamic Banking in Bangladesh ; Expectation and realities" and argued that these to types of banks differ only in appearance but not in substance.

Shallah (1989) made a study on Islamic Banking in an interest based economy - A case study of Jordan. The findings of the research showed that the Jordan Islamic bank has proved viable compared to interest based banks on Jordan.

Sources of data collection

The data collected from IBBL are classified into two categories. Such as:

(I) Collection of Primary Data

The primary data are collected from practical desk work, face to face conversation with the executives and officers, face to face conversation with the clients, personal observation etc.

(II) Collection of Secondary Data

We collected a huge number of secondary data also with a view to preparing a good research paper. The secondary data are taken from annual report of IBBL, other published information such as journals, magazines, papers etc., book let of Islamic bank etc., branch manager's conference ranging 2008 to 2010, and thesis on Islamic banking.

\section{Analysis of the Study}

\subsection{Concept of Credit Performance}

To measure the credit performance of the IBBL we can use the following techniques:

\subsubsection{Growth Rate of Total Credit}

Growth Rate of Total credit

$$
=\frac{(\text { Current year }- \text { Previous year })}{\text { Previous year }} \times 100
$$

(Amount in million Taka)

$$
\begin{aligned}
& 2007=\frac{165286.32-117132.83}{117132.83} \times 100=41.110 \\
& 2008=\frac{187586.55-117132.83}{117132.83} \times 100=60.148 \\
& 2009=\frac{225752.41-117132.83}{117132.83} \times 100=92.731 \\
& 2010=\frac{275493.94-117132.83}{117132.82} \times 100=135.197
\end{aligned}
$$

Table1.Computation of Growth Rate of Total Credit of IBBL(Amount in \%).

\begin{tabular}{llll}
\hline Year & Total credit of respective year(Current year) & Total credit of base year (2006) & Growth rate \\
\hline 2006 & 117132.83 & 117132.83 & - \\
2007 & 165286.32 & 117132.83 & 41.110 \\
2008 & 187586.55 & 117132.83 & 60.148 \\
2009 & 225752.41 & 117132.83 & 92.731 \\
2010 & 275493.94 & 117132.83 & 135.197 \\
\hline
\end{tabular}

Source: Annual Report 2010

Mean $=63.84$

$\mathrm{SD}=50.14$

$\mathrm{CV}=78.537$ 


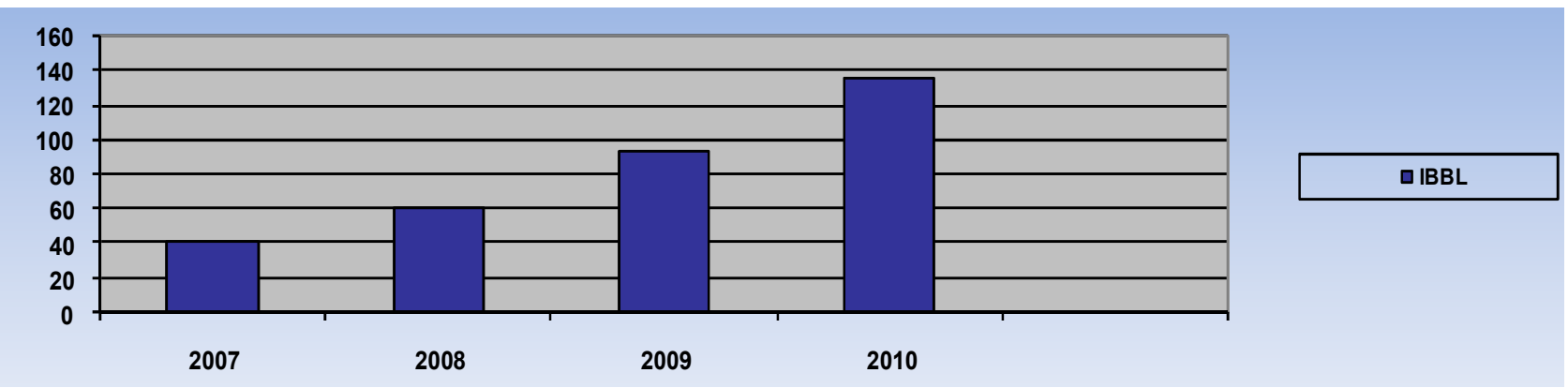

Figure 1.Bar Diagram of Growth Rate of Total Credit.

In the above fig. 1 shows that Growth rate of Total credit shows the positive or negative tendency of people to collect their fund from the respective institutions. The higher the growth rate of total credits the best for the organization and its profitability. From the table mentioned above it is found that, the highest growth rate of total credit shows in 2010. It is so good for the organization.

\subsubsection{Measurement of Credit to Volume of Working Fund}

Credit to Volume of Working Fund

$$
=\frac{\text { Total Credit }(\text { Investment })}{\text { Total Volume of Working Fund }} \times 100
$$

(Amount in million Taka)

$$
\begin{aligned}
& 2008=\frac{187586.55}{230879.14} \times 100=81.249 \\
& 2009=\frac{225752.41}{278320.84} \times 100=81.118 \\
& 2010=\frac{275493.94}{330586.12} \times 100=228.53
\end{aligned}
$$

\begin{tabular}{|c|c|c|c|c|c|c|c|c|}
\hline Year & 2006 & 2007 & 2008 & 2009 & 2010 & Mean & SD & CV \\
\hline Credit to Volume of Working Fund & 77.95 & 86.37 & 81.25 & 81.12 & 228.53 & 111.05 & 65.75 & 59.21 \\
\hline
\end{tabular}

Table2. Computation of Credit to VWF of IBBL (Amount in \%).

Source: Annual Report 2010(VWF = Total Asset Excluding Contra)

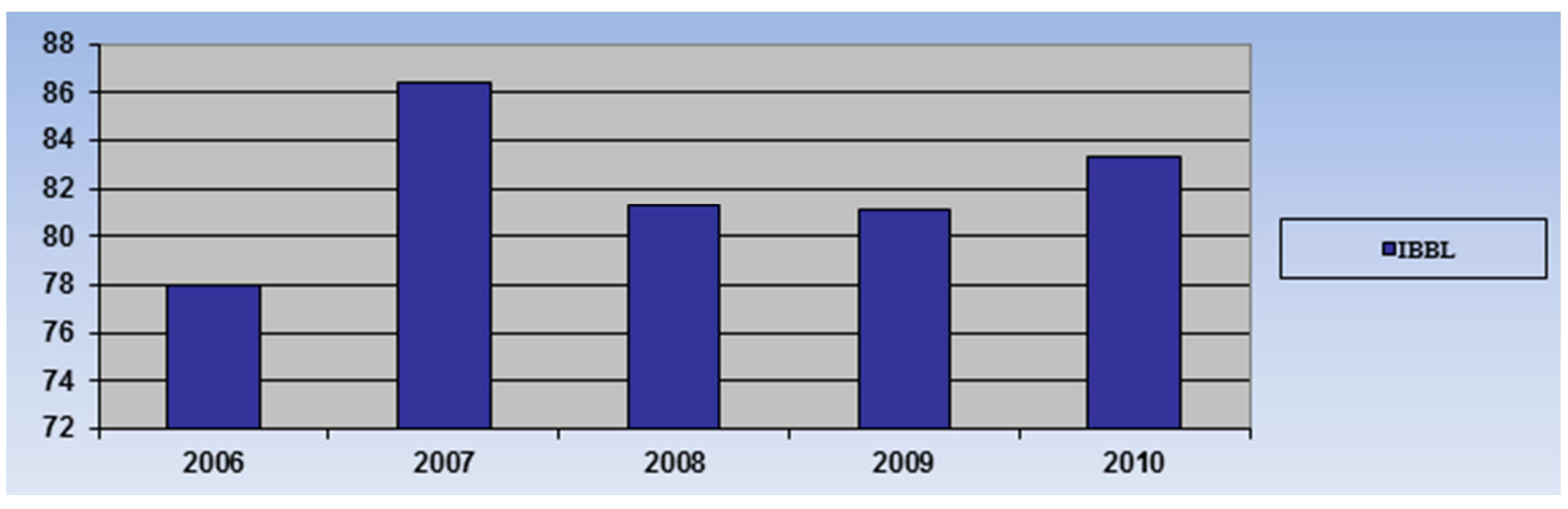

Figure 2.Measurement of credit to volume of working funds.

In the above fig. 2 shows that the higher the rate of credit to volume of working funds the better for the organization. On the other hand it is more risky also.Taking into consideration the above table it is found that, the average rate of credit to volume of working funds of IBBL is the higher in 2010, 2007 and 2008. So it earns best performance in those year.

\subsection{Measurement of classified Investment to Total Investment}

Classified Investment to Total Investment

$$
=\frac{\text { Total Classified Investment }}{\text { Total Investment }} \times 100
$$

(Amount in million Taka)

$$
\begin{aligned}
& 2008=\frac{4311.13}{180053.94} \times 100=2.39 \\
& 2009=\frac{5063.40}{214615.80} \times 100=2.36 \\
& 2010=\frac{4655.63}{263225.13} \times 100=1.77
\end{aligned}
$$


Table3.Computation of Classified Investment to Total Investment of IBBL(Tk. in \%).

\begin{tabular}{|c|c|c|c|c|c|c|c|c|}
\hline Year & 2006 & 2007 & 2008 & 2009 & 2010 & Mean & SD & CV \\
\hline Classified Investment to Total Investment & 3.43 & 2.93 & 2.39 & 2.36 & 1.77 & 2.58 & 3.11 & 120.58 \\
\hline
\end{tabular}

Source: Annual Report 2010

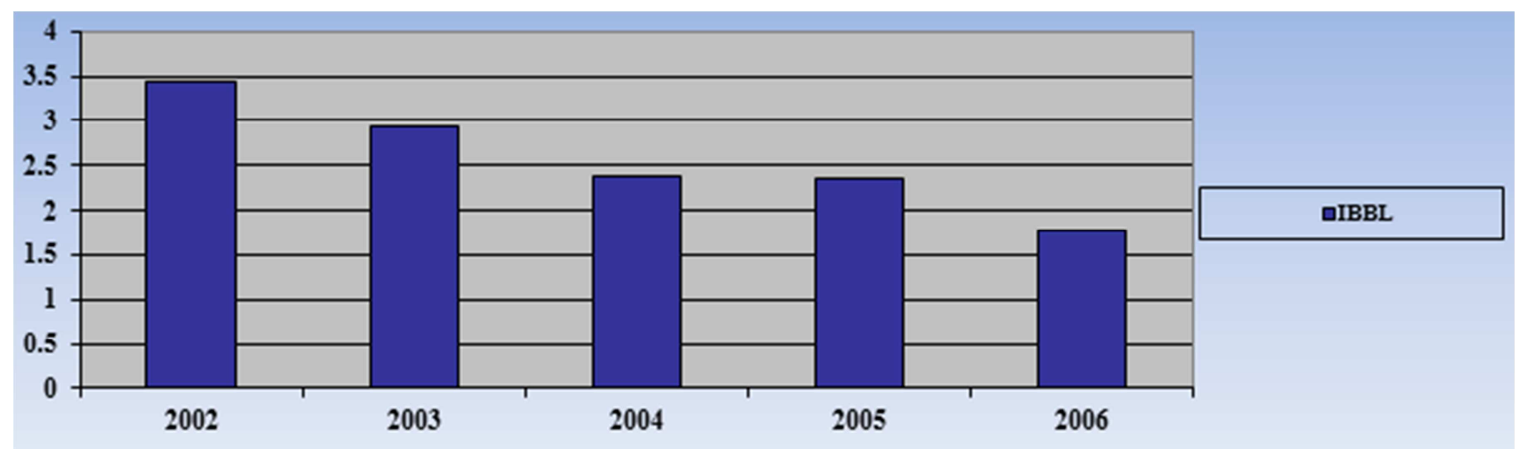

Figure 3.Measurement of classified Investment to total Investment.

In the above fig.3 shows that the smaller the rate of classified investment to total Investment the better for the organization. The above table shows us that the average rate of classified investment to total loan of IBBL is too much lower in 2007, 2008, 2009 and 2010.So those years shows the best performance.

\subsection{Measurement of Profitability}

To measure the profitability of IBBL we can use the following techniques:-
Return on Asset $=\frac{\text { Net Profit after Tax }}{\text { Total Asset Escluding Contra }} \times 100$

(Amount in million Taka)

$$
\begin{aligned}
& 2008=\frac{2674.8}{230879.14} \times 100=1.223 \\
& 2009=\frac{3403.55}{278302.84} \times 100=1.350 \\
& 2010=\frac{4655.63}{263225.13} \times 100=1.082
\end{aligned}
$$

\begin{tabular}{|c|c|c|c|c|c|c|c|c|}
\hline Year & 2006 & 2007 & 2008 & 2009 & 2010 & Mean & SD & $\mathrm{CV}$ \\
\hline Return on Asset & 0.93 & 0.75 & 1.16 & 1.22 & 1.35 & 1.08 & 0.24 & 22.31 \\
\hline
\end{tabular}

\subsubsection{Return on Asset}

Table4. Computation of Return on Asset of IBBL (Amount in \%).

Source: Annual Report 2010

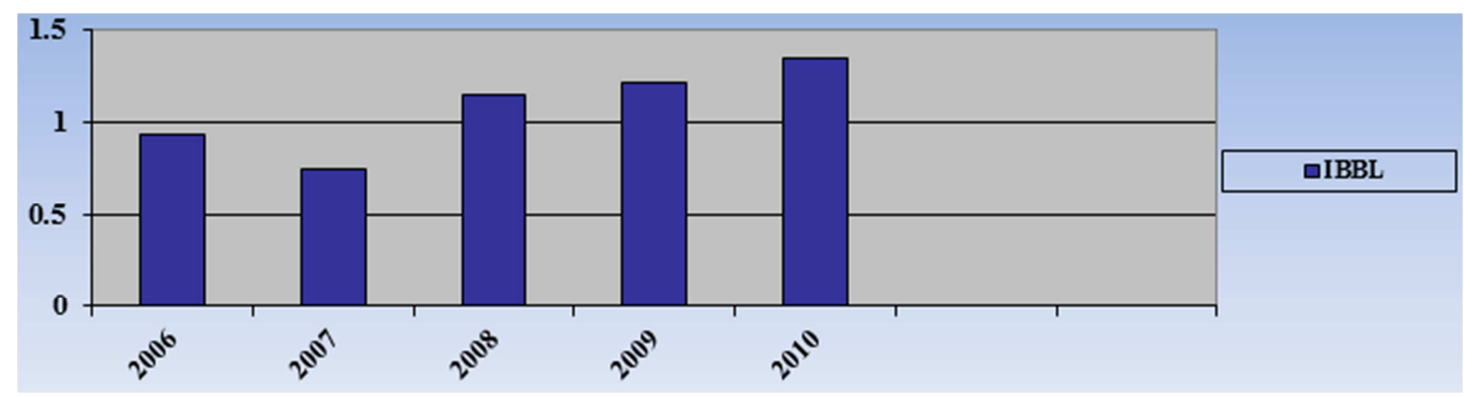

Figure4. Bar Diagram of Return on Asset of IBBL.

From the above table- 4 indicates that, the average return on asset ratio in 2009 is higher among the year. It is too much good for organization. But the standard deviation and coefficient of variation is not smaller. So it does not show least risky in return on asset.

\subsubsection{Return on Equity}

Return on Equity $=\frac{\text { Gross Profit }}{\text { Total Equity }} \times 100$

(Amount in million Taka) 


$$
\begin{aligned}
& 2008=\frac{6347.83}{18572.08} \times 100=27.594 \\
& 2009=\frac{6517.66}{23619.81} \times 100=29.770
\end{aligned}
$$

$$
2010=\frac{8454.7}{28400.03} \times 100=28.938
$$

\begin{tabular}{|c|c|c|c|c|c|c|c|c|}
\hline Year & 2006 & 2007 & 2008 & 2009 & 2010 & Mean & SD & $\mathrm{CV}$ \\
\hline Return on Equity & 27.872 & 25.277 & 34.179 & 27.594 & 29.770 & 28.938 & 3.336 & 11.527 \\
\hline
\end{tabular}

Table5.Computation of Return on Equity of IBBL (Amount in \%).

Source: Annual Report 2010

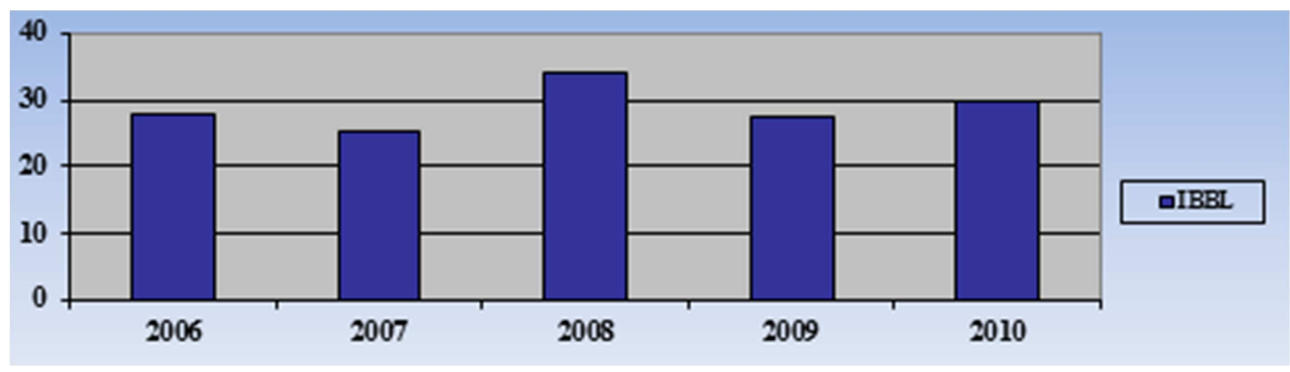

Figure5. Bar Diagram of Return on Equity of IBBL.

From the above table-5 implies that, the standard deviation and coefficient of variation of the

Bank in return on equity is higher. So IBBL shows high risky in return on equity.

\subsection{Measurement of Productivity}

The measurement of productivity is calculated by the following techniques:

\subsubsection{Deposit per Branch}

$$
\text { Deposit per Branch }=\frac{\text { Total Depodit }}{\text { Total No. of Branch }}
$$

\begin{tabular}{|c|c|c|c|c|c|c|c|c|}
\hline Year & 2006 & 2007 & 2008 & 2009 & 2010 & Mean & SD & $\mathrm{CV}$ \\
\hline Deposit per Branch & 752.38 & 894.22 & 981.14 & 1057.54 & 1163.09 & 969.68 & 4.15 & 0.43 \\
\hline
\end{tabular}

(Amount in million Taka)

$$
\begin{aligned}
& 2008=\frac{202115.45}{206}=981.143 \\
& 2009=\frac{244292.14}{231}=1057.54 \\
& 2010=\frac{291934.6}{251}=1163.086
\end{aligned}
$$

Table6. Computation of Deposit Per Branch of IBBL (Amount in million Taka).

Source: Annual Report 2010

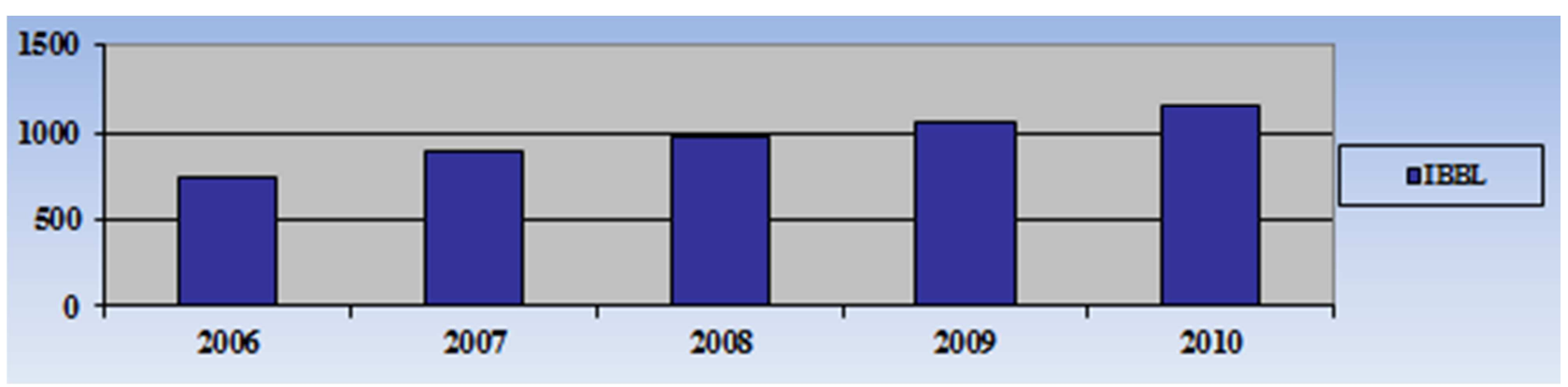

Figure6. Bar Diagram of Deposit per Branch of IBBL.

From the above table-7 indicates that, the average deposit per branch ratio of IBBL is comparatively higher. It is too much good for organization. But the standard deviation and coefficient of variation is also smaller. So IBBL shows least risky in return on asset.

\subsubsection{Profit per Branch}

Profit per Branch $=\frac{\text { Total Profit received on Investment }}{\text { Total No. of Branch }}$ (Amount in million Taka) 


$$
\begin{aligned}
& 2008=\frac{19952.59}{206}=96.857 \\
& 2009=\frac{21485.69}{231}=93.012
\end{aligned}
$$$$
2010=\frac{25224.42}{251}=100.49
$$

Table7. Computation of Interest or Profit per Branch of IBBL (Amount in million Taka).

\begin{tabular}{lllllllll}
\hline Year & $\mathbf{2 0 0 6}$ & $\mathbf{2 0 0 7}$ & $\mathbf{2 0 0 8}$ & $\mathbf{2 0 0 9}$ & $\mathbf{2 0 1 0}$ & Mean & SD & CV \\
\hline Profit per Branch & 64.18 & 79.87 & 96.86 & 93.01 & 100.50 & 86.88 & 14.89 & 17.14 \\
\hline
\end{tabular}

Source: Annual Report 2010

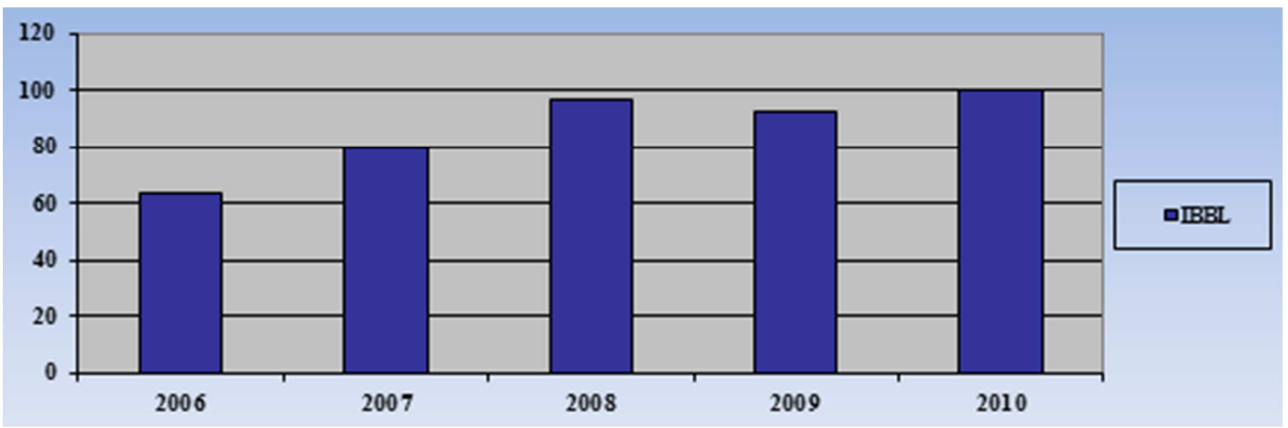

Figure7.Bar Diagram of Interest or Profit Per Branch of IBBL.

From the above table- 8 shows that, the average profit per branch ratio of IBBL is higher yearly. It is too much good. But the standard deviation and coefficient of variation is comparatively high. So IBBL shows high risky in return on asset.

\subsection{Measurement of Solvency}

To measure the solvency of the selected banks to measure the actual performance of IBBL we can use the following techniques:

\subsubsection{Current Ratio}

$$
\text { Current Ratio }=\frac{\text { Total Current Asset }}{\text { Total Current Liabilities }}
$$

(Amount in million Taka)

\begin{tabular}{|c|c|c|c|c|c|c|c|c|}
\hline Year & 2006 & 2007 & 2008 & 2009 & 2010 & Mean & SD & $\mathrm{CV}$ \\
\hline Current Ratio & 3.97 & 3.26 & 4.04 & 4.47 & 2.92 & 3.73 & 0.42 & 11.18 \\
\hline
\end{tabular}

$$
\begin{aligned}
& 2008=\frac{230879.14}{57138.05}=4.041 \\
& 2009=\frac{278302.84}{62335.65}=4.465 \\
& 2010=\frac{330586.12}{113098.67}=2.923
\end{aligned}
$$

Table8. Computation of current ratio of IBBL (Amount in million Taka).

Source: Annual Report 2010

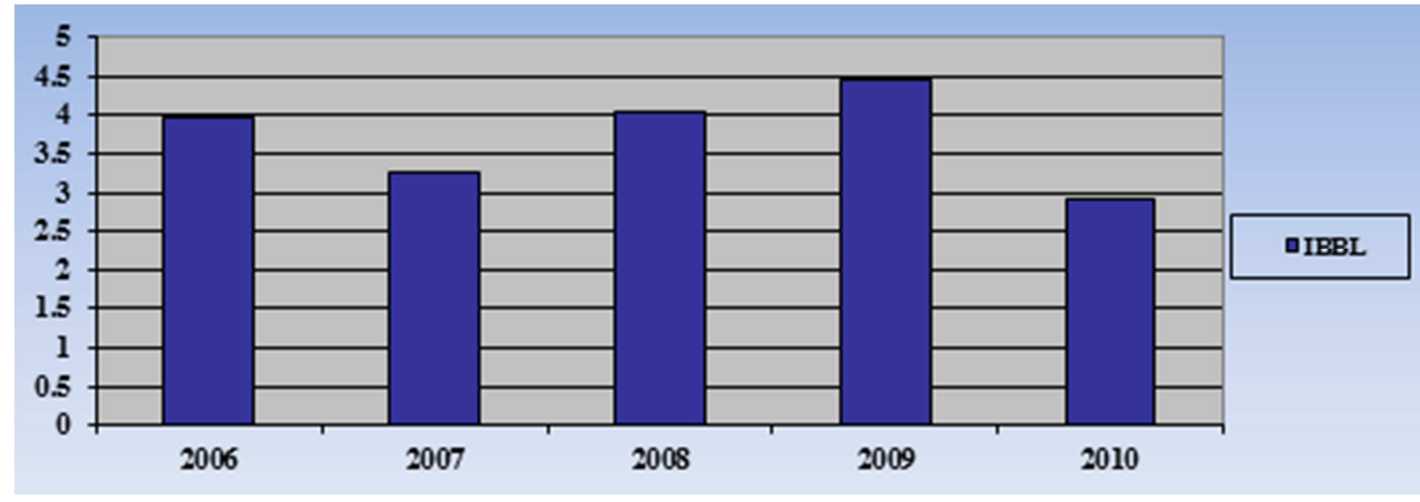

Figure8. Bar Diagram of Current Ratio of IBBL.

From the above table- 9 it is found that, the average current ratio of IBBL is highest in maximum year. It is too much good for IBBL. But the coefficient of variation of IBBL is the smaller. So IBBL shows least risky as well as more favorable 
current ratio than previous.

\subsubsection{Quick Ratio}

$$
\text { Quick Ratio }=\frac{\text { Total Quick Asset }}{\text { Total current Liabilities }}
$$

Table9. Computation of quick ratio of IBBL (Amount in million Taka).

\begin{tabular}{|c|c|c|c|c|c|c|c|c|}
\hline Year & 2006 & 2007 & 2008 & 2009 & 2010 & Mean & SD & $\mathrm{CV}$ \\
\hline Quick Ratio & 3.31 & 2.26 & 4.03 & 4.00 & 2.12 & 3.70 & 0.92 & 24.78 \\
\hline
\end{tabular}

Source: Annual Report 2010

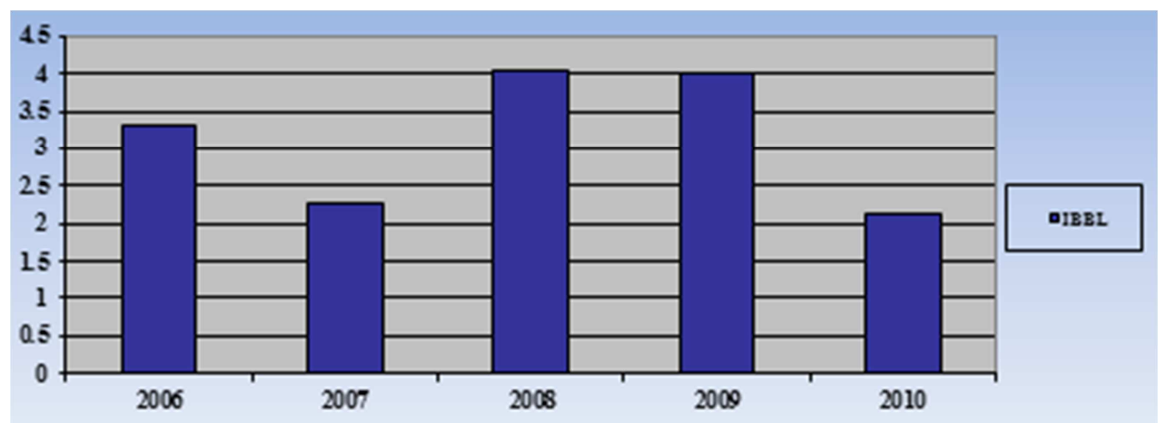

Figure9.Bar Diagram of Current Ratio of IBBL.

From the above table-10 it is found that, the average quick ratio of IBBL is the highest among the banks. It is too much good for IBBL. But the coefficient of variation of IBBL is the smaller than that of others. So IBBL shows least risky as well as more favorable quick ratio.

\subsection{Risk Measurement}

$$
\text { Debt to Equity Ratio }=\frac{\text { Total Debt }}{\text { Total Equity }}
$$

\begin{tabular}{|c|c|c|c|c|c|c|c|c|}
\hline Year & 2006 & 2007 & 2008 & 2009 & 2010 & Mean & SD & $\mathrm{CV}$ \\
\hline Debt to Equity Ratio & 25.27 & 20.30 & 21.10 & 17.20 & 20.15 & 20.80 & 2.90 & 13.95 \\
\hline
\end{tabular}

Table10. Computation of debt to equity ratio of IBBL (Amount in million Taka).

Source: Annual Report 2010

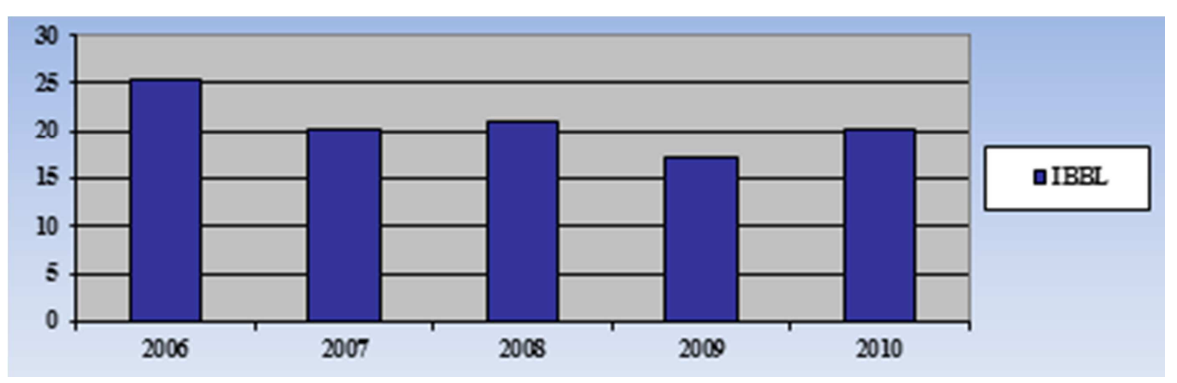

Figure10. Bar Diagram of Debt to equity ratio of IBBL.

From the above table-11 it is found that the average and coefficient of variation of IBBL in debt to equity ratio is not more favorable than previous record. So IBBL shows risky ratio of debt to equity.

\section{Findings of the study}

After analyzing various data the following findings are shown:

1. Growth rate has in increasing trend.

2. Though profit of IBBL is increasing but it remains in risky position.
3. The yearly productivity is greater than ever.

4. The return on asset of IBBL is in hazard.

\section{Recommendations}

It is not unexpected to have many Problems in any Organization for this reason already we have found many problems of financial performance of IBBL. To solve these problems I can suggest following recommendations.

1. Attention should be given to minimize the risks associated with profitability.

2. IBBL should try to raise the more deposit ratio for 
carrying higher productivity in future.

3. The risk of returned on equity should be reduced.

4. An increasing trend should be obtained in the case of solvency.

\section{Conclusion}

In fine we can conclude that, the profit of IBBL is free of traditional interest. The result of various ratio analysis shows that financial performance of IBBL is holding a better position. For economic development of Bangladesh it is playing a crucial role. For making sustainable profitability this bank should minimizes its risks. We hope this bank will increase its financial performance in future for earning a worldwide reputation and establishing profitable image.

\section{References}

[1] Al Quran. (Bangla translate Tafhimul Quran)(Sura: Bakara188,275, 278; Rum-39; Al-Imran-161; Nesa-29-30; Kasas-77, and Hadith (Bukhari\& Muslim Sharif)

[2] Annual reports of Islami Bank Bangladesh Ltd. 2010

[3] Dr. M.N Siddiqi: Some Aspects of Islamic Economy.
[4] Horn green, C.T.Cost Accounting.

[5] Islami Bank 5 Years of Progress, Islami Bank Bangladesh Limited, Based on Islamic Economic Research Bureau: Thoughts on Islamic Economic Banking.

[6] Khan.M.Y. And Jain, P.K: Financial Management, Tata McGraw-Hill

[7] Kothari, C.K. Research Methodology.

[8] Mannan M.A.: Islamic Economic: Theory and Practice.

[9] Pandy, I.M: Financial Management.

[10] Rose and westerfield: Financial Management

[11] Sina, Dr.Md.Abu. The Modes of Investment of Islami banks and Conventional Nationalized Commercial bank (A comparative study, P.H.D thesis, Department of Account, Islamic University, Kushtia.)

[12] Hannan, A.S. and Shaheed, A. 1998 Financial Position and Performance analysis of BangladeshShilpa Bank, Islamic University Studies, Volume-1, June 1998.

[13] Shekar, K.C.: Bank Management.

[14] Shekar, K.C.: Banking Theory and Practice.

[15] Weston, J.F. \& Brigham, F.E.: Managerial Fina 